\title{
Vitamin C in-vivo Effect on Liver Enzymes and Some Endogenous Antioxidants in Paracetamol-Induced Model of Liver Toxicity on Wistar Rats
}

\author{
${ }^{1 *}$ MOKE, EG; ${ }^{2}$ ANACHUNA, KK; ${ }^{3}$ ONYILO, PO; ${ }^{1}$ EMOSIVBE, M
}

\author{
${ }^{1}$ Department of Pharmacology and Therapeutics, ${ }^{2}$ Department of Physiology, ${ }^{3}$ Department of Human Anatomy and Cell Biology Delta State \\ University, Abraka, Delta State, Nigeria. \\ *Corresponding Author.E-mail: hiligoodies@gmail.com; Tel: +234-7061040692
}

\begin{abstract}
This study aimed at assessing the in-vivo effect of Vitamin C on liver enzymes and some endogenous antioxidants in paracetamol-induced model of liver toxicity on Wistar rats. The rats were grouped into four groups of five animals each; groups 1 and 2 were control (positive and negative), while group 3 and 4 received vitamin C $500 \mathrm{mg} / \mathrm{kg}$ and silymarin $100 \mathrm{mg} / \mathrm{kg}$ respectively. Dosing was oral and daily for 6 days according to their body weights. All the animals except the positive control group (Group 1) were administered paracetamol $3 \mathrm{~g} / \mathrm{kg}$ on the $7^{\text {th }}$ day, and then observed for 24 hours before sample collection for biochemical indices and liver histological studies. Paracetamol caused a significant $(\mathrm{p}<0.05)$ increase in liver enzymes, significant $(\mathrm{p}<0.05)$ decrease in antioxidant enzymes, and necrosis in liver tissues when compared to the control. Administration of $500 \mathrm{mg} / \mathrm{kg}$ Vitamin C prior to induction of liver damage by PCM resulted in significant $(p<0.05)$ decreased liver enzyme and well as an increase in the antioxidant enzymes. Pre-treatment of the animals with vitamin $\mathrm{C}$ showed a reversal of the toxic effect of paracetamol on the rats.
\end{abstract}

DOI: https://dx.doi.org/10.4314/jasem.v23i7.20

Copyright: Copyright $($ C 2019 Moke et al. This is an open access article distributed under the Creative Commons Attribution License (CCL), which permits unrestricted use, distribution, and reproduction in any medium, provided the original work is properly cited.

Dates: Received: 30 May 2019; Revised: 25 June 2019; Accepted 13 July 2019

Keywords: Vitamin C, liver enzymes, paracetamol, toxicity.

The body is made up of many organs that play important roles in maintaining homeostasis. The liver is one of such organ involved in the metabolism and biotransformation, secretion and storage of chemical substances (Adewusi and Aforlayan, 2010). The basic functions of the liver also includes detoxification, protein synthesis, regulation of glycogen storage, decomposition of red blood cells and hormone production among others, as well as, act as store for certain substances such as glucose, iron, copper and the vitamins (Hirschfield and Gershwin, 2013). Because of its multiple functions, the liver is well prone to many diseases (hepatitis). Disease of the liver leads to damage to the cells, tissues, structure, or function of the liver. Such damage may be induced by toxic compounds (including drugs such as paracetamol) as well as other biological factors (Casafont-Morencos et al., 2008). The hepatotoxic effect of paracetamol is due to its toxic metabolite, Nacetyl-p-benzoquinineamine which binds to macromolecules of the liver cells resulting in cell necrosis (Rang et al., 2007). Liver function tests are carried out to diagnose hepatic diseases, which involves blood tests that can identify various biomarkers such as the transaminases (aspartate transaminase and alanine transaminase) and alkaline (Mcclatchey, 2002). Hepatotoxic agents induce increased production of reactive oxygen species (ROS) in the body, and these radicals attack biological molecules such as lipids, proteins and DNA. Administration of antioxidants which can scavenge the free radicals could reduce the hepatic injury (Cotran et al., 2005). Vitamin C was discovered by Szent-Gyorgyi in 1928 (Grzybowski and Pietrzak, 2013). It is a six-carbon compound structurally related to glucose, consisting of two inter-convertible compounds: L- ascorbic acid, which is a strong reducing agent, and its oxidized derivative, $\mathrm{L}$ dehydroascorbic acid. It is present in fruits and leafy green vegetables, and in food sources such as kidney and liver. Vitamin $\mathrm{C}$ is an important free radical scavenger, trapping radicals and guarding biomembranes from peroxide injury. Vitamin $\mathrm{C}$ efficiently scavenges singlet oxygen, superoxide, hydroxyl, water soluble peroxylradical and hypochlorous acid (Cortés-Jofré et al., 2012). It is an essential co-factor involved in many biochemical functions and acts as an electron donor or reducing agent to free radicals such as hydroxyl and super oxide radicals, thus, extinguishing their activity (Luo et al., 2014). Vitamin $C$ has been reported by researchers to have hepatoprotective property, which is attributed to its antioxidant property (Stratton and Godwin 2011). This study aims at assessing the in-vivo effect of 
Vitamin C on liver enzymes and some endogenous antioxidants in paracetamol-induced model of liver toxicity on Wistar rats.

\section{MATERIALS AND METHODS}

Animals: Twenty (20) adult wistar rats weighing between 160-190 g were procured from the Animal House of the Faculty of Basic Medical Science, Delta State University Abraka, Nigeria. The animals were acclimatized for a period of two weeks prior to the study, and were placed on Growers' feed and clean water ad libitum. Guidelines followed in the handling of animals were in accordance with the ethical standards of the Institutional Animals Ethics (IAEC), as adopted by the ethical committee of the Faculty of Basic Medical Science, Delta State University, Abraka, Nigeria (FBS/CT/091720).

Drugs: Paracetamol (PCM) $500 \mathrm{mg}$ tablet (Emzor, Nigeria)

Vitamin C $100 \mathrm{mg}$ tablets (Emzor, Nigeria)

Silymarin $100 \mathrm{mg}$ tablet (Silybon ${ }^{\circledR}$; Micronova, India)

Preparation of drug solution: Five tablets of $100 \mathrm{mg}$ of vitamin C (total of $500 \mathrm{mg}$ ) were powdered with the aid of a mortar and pestle, and dissolved in $10 \mathrm{ml}$ of normal saline. The solution was refrigerated prior to use.

Paracetamol-induced hepatotoxicity: The animals (rats) were randomly placed into 4 groups of 5 animals each as follows:

Group 1 - Normal Saline (NS) $10 \mathrm{ml} / \mathrm{kg}$

Group 2 - Normal Saline (NS) $10 \mathrm{ml} / \mathrm{kg}$ + PCM 3000

$\mathrm{mg} / \mathrm{kg}\left(7^{\text {th }}\right.$ Day)

Group 3 - Vitamin C (VIT C) $500 \mathrm{mg} / \mathrm{kg}$ + PCM 3000 $\mathrm{mg} / \mathrm{kg}$ ( $7^{\text {th }}$ Day)

Group 4 - Silymarin 100 mg/kg + PCM 3000 mg/kg ( $7^{\text {th }}$ Day)

The experimental animals were administered the drugs solutions orally daily for 6 days according to their body weights. All the animals except the normal control group (Group 1) were administered PCM 3000 $\mathrm{mg} / \mathrm{kg}$ on day 7 and then observed for 24 hours (Ramachandra et al., 2007) before they were sacrificed for sample collection. The animals were subjected to chloroform anaesthesia and blood samples were drawn, allowed to clot, centrifuged and serum collected to analyze for the biochemical indices. The liver of each animal was harvested for histopathological studies.

Determination of liver enzymes function test: Alkaline phosphatase (ALP), aspartate aminotransefrase (AST), and alanine transaminase (ALT) in serum were determined according to methods described by Reitman and Frankel (1957) and Roy (1970).

Determination of antioxidants activity: Superoxide dismutase (SOD), and catalase (CAT) were analyzed using methods of Misra and Fredovich (1972), Sinha (1972).

Histopathology: Sections of liver samples fixed with formalin, were stained with haematoxylin-eosin for photomicroscopic observations of the liver histological architecture.

Data analyses: Results were presented as mean \pm standard error of mean (SEM) using one-way analysis of variance (ANOVA) followed by Tukey's post hoc test. P-values $<0.05$ were taken as significant.

\section{RESULTS AND DISCUSSION}

Effect of vitamin $C$ on serum liver enzymes in paracetamol induced hepatotoxicity: Statistically significant $(\mathrm{p}<0.05)$ increase was observed in all the liver enzymes (AST, ALT, and ALP) of experimental animals in PCM control (negative) group as compared with those in the normal (positive) control group. Administration of $500 \mathrm{mg} / \mathrm{kg}$ Vitamin $\mathrm{C}$ prior to induction of liver damage resulted in significant $(p<0.05)$ decreased liver enzyme in experimental rats as compared to the PCM treated group (Table 1). Significant $(\mathrm{p}<0.05)$ decrease in liver enzymes were detected in rats administered silymarin (standard drug) as compared with the PCM control group.

Table 1: The effect of Vitamin C on liver enzymes in paracetamol induced hepatotoxicity

\begin{tabular}{|c|c|c|c|}
\hline & AST (U/L) & ALT (U/L) & ALP(U/L) \\
\hline$\overline{\mathrm{NS}}$ & $46.41 \pm 1.51$ & $15.53 \pm 1.80$ & $31.23 \pm 3.27$ \\
\hline $\mathrm{NS}+\mathrm{PCM}$ & $69.72=0.94^{a}$ & $26.92=3.18^{a}$ & $55.77=1.18^{4}$ \\
\hline $\mathrm{VITC}+\mathrm{PCM}$ & $49.25=2.20^{b}$ & $10.11=0.49^{b}$ & $40.76=7.47^{b}$ \\
\hline Silymarin - PCM & $50.86=0.75^{b}$ & $13.94=1.85^{b}$ & $40.42=2.04^{b}$ \\
\hline
\end{tabular}

Table 2: The effect of Vitamin $\mathrm{C}$ on some on antioxidant enzymes in paracetamol induced hepatotoxicity

\begin{tabular}{|c|c|c|}
\hline & SOD (IU/L) & CATALASE (IU/L) \\
\hline NS & $0.31 \pm 0.03$ & $0.52 \pm 0.06$ \\
\hline NS + PCM & $0.27 \pm 0.06^{\mathrm{a}}$ & $0.45 \pm 0.09^{\mathrm{a}}$ \\
\hline VITC + PCM & $0.91 \pm 0.04^{b}$ & $1.17 \pm 0.04^{b}$ \\
\hline Silymarin + PCM & $1.21 \pm 0.51^{\mathrm{b}}$ & $1.51 \pm 0.04^{\mathrm{b}}$ \\
\hline
\end{tabular}

Effect of vitamin C on some serum antioxidants levels in paracetamol induced hepatotoxicity: Significant 
$(p<0.05)$ decrease in antioxidant enzymes (SOD, and $\mathrm{CAT}$ ) were observed in PCM control group as against those in normal control group. A significant $(p<0.05)$ increase in the antioxidant enzymes was observed in rats administered $500 \mathrm{mg} / \mathrm{kg}$ of Vitamin $\mathrm{C}$ and those given silymarin when compared with the PCM control group (Table 2).

Histopathology: Histological observations of the liver tissues showed massive necrosis of hepatocytes and congestion, with extensive infiltration of lymphocytes and Kupffer cells induced by PCM. Pre-t treatments with vitamin $C$ and silymarin markedly prevented the hepatic lesions induced by the toxin (Figure 1).

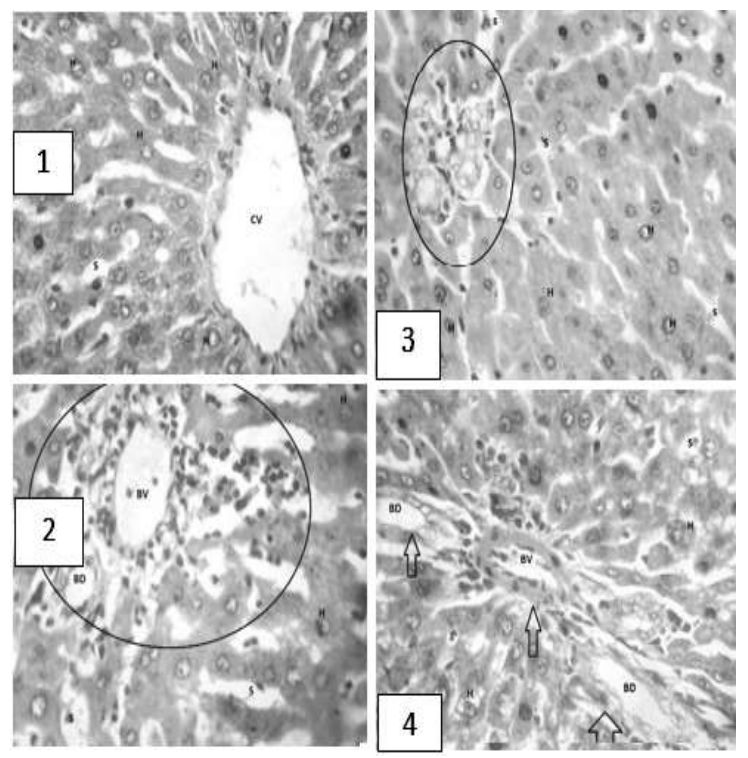

Fig 1: Effect of vitamin C on PCM-induced liver damage in rats. (1) Normal control group - normal hepatic tissue, free from inflammatory cells and congestion ( $\times 400)$; (2) PCM (Toxin) group - marked periportal hepatitis (circle) with congestion, and the hepatic tissue infiltrated by inflammatory cells ( $\times$ 400); (3) Vitamin C $500 \mathbf{~ m g / k g ~ t r e a t e d ~ g r o u p ~ - ~ h e p a t o c y t e s ~ w i t h ~ m i l d ~ i n f l a m m a t o r y ~}$ cells ( $\times$ 400); (4) Silymarin $100 \mathrm{mg} / \mathrm{kg}$ treated group - normal hepatocytes with mild periportal inflammatory cells infiltration $(\times$ 400).

Drugs are chemical substances or agents used for the chemotherapy of diseases. However, some drugs are known to have hepatotoxic effects in human and animals. These drug-induced liver disorders occur frequently and can be life-threatening (CasafontMorencos et al., 2008). For example, the widely used analgesic and antipyretic drug, paracetamol, produces acute liver damage in high doses. This liver damage is due to its toxic metabolite (N-acetyl-pbenzoquinone imine - NAPQI) which is produced by cytochrome P-450 enzymes in the liver (Rang et al., 2007). NAPQI, covalently binds to oxidized lipids and sulphydryl groups of proteins of the liver tissue resulting to the severe damage of cell membranes
(Kupeli et al., 2006). The resultant effects of free radical such as lipid peroxidation, protein oxidation and DNA oxidation are rarely the cause of cell death in realistic in-vivo condition (Jaeschke et al., 2003). This is because the liver cells antioxidants defense system detoxifies these free radicals and repair damage resulting from highly reactive metabolites (Jaeschke et al., 2003). Overwhelmed antioxidant defense system results in these free radicals inflicting direct oxidative damage to cellular macromolecules, leading to cell death (Sabiu et al., 2014). Presumably, when hepatic GSH diminish by about 70\%, NAPQI becomes available for inducing a cascade that may result in hepatic cell death (Larson, 2007).

The most sensitive biomarkers used in the diagnosis of hepatic damage is the serum level of the liver enzymes aspartate aminotransferase (AST), alanine transaminase (ALT), and alkaline phosphatase (ALP). They are cytoplasmic enzymes released into circulation after cellular damage in acute hepatotoxicity (Mitra et al., 1991). Results from this study showed a significant $(\mathrm{p}<0.05)$ elevation in the activities of liver enzymes (ALT, AST and AST) of rats which was induced by paracetamol (PCM) $3 \mathrm{~g} / \mathrm{kg}$ in the negative control group when compared with the rats of the control group (Table 1). However, this study showed that prior administration with the exogenous antioxidant vitamin $\mathrm{C}$ (ascorbic acid) augmented the cellular defense system to prevent these ill effects on cellular macromolecules in rat model of paracetamolinduced liver damage. A statistically significant $(\mathrm{p}<$ 0.05 ) decrease in the levels of serum marker enzymes (ALT, AST and AST) of rats pretreated with Vitamin $\mathrm{C}$ prior to PCM dosing when compared with the PCM control group. This effect correlated with that of the standard drug silymarin, an antioxidant and a hepatoprotective agent which is well distributed in the body particularly in the red blood cells and in the liver (Presser et al., 2000). Hepatotoxicity induced by paracetamol significantly $(\mathrm{p}<0.05)$ decreased serum levels of superoxide dismutase (SOD) and catalase $(\mathrm{CAT})$ in the rats. There was a significant $(\mathrm{p}<0.05)$ improvement (increase) in both SOD and CAT levels measure in animals pretreated with vitamin $C$ when compared with the PCM control group (Table 2). Increased levels of the antioxidant indices by vitamin $\mathrm{C}$ was very much similar to that of the standard drug silymarin. Histological analysis of the liver presented a marked periportal hepatitis with the hepatic tissue infiltrated by inflammatory cells in rats dosed with paracetamol only. Paracetamol administration causes necrosis of the centrilobular hepatocytes characterized by nuclear pyknosis and eosinophilic cytoplasm followed by large excessive hepatic lesion (Eesha et al., 2011). Both vitamin $C$ and silymarin prevented 
hepatic necrosis following pretreatment before paracetamol dosing, as the hepatocytes appeared normal with mild periportal inflammatory cells infiltration. Studies have reported the antioxidants and cytoprotective activities of vitamin $\mathrm{C}$ and silymarin (Mor and Ozmen, 2010). Vitamin C has shown tremendous protective effect against hepatotoxicity induced by drugs and chemical agents (Gaafa et al., 2011; Al-Shathly et al., 2012). These results raised the possibility that vitamin $\mathrm{C}$ may be useful in preventing hepatic injury caused by the hepatotoxic drug paracetamol.

Conclusion: Vitamin $\mathrm{C}$ is an efficacious hepatoprotective agent as clearly demonstrated by this study which is evident from its improvement of antioxidant enzymes (superoxide dismutase and catalase), positive effect on liver enzymes, and reversal of liver tissue necrosis. Diet supplementation with vitamin $\mathrm{C}$ will be beneficial to health in protecting the liver from damage by hepatotoxic chemicals.

Acknowledgements: We wish to acknowledge the laboratory contributions of Godwin C Ahatty, Chief Laboratory Technologist of the Laboratory of Pharmacology, Delta State University, Abraka, Nigeria.

\section{REFERENCES}

Adewusi, EA; Afolayan, AJ (2010). A review of natural products with hepatoprotective activity. $J$. Med. Plants Res. 4: 1318-1334.

Al-Shathly, MR; Mujallid, MI; Al-Sharif, EA; Alqurashi, MM (2012). The preventive effect of vitamin c upon added methyl tertiary butyl ether (MTBE) in drinking water on the liver of albino mice. IJRCE 2(2): 214-228.

Casafront-Morencos, F; Puente, A; Pons-Romero, F (2008). Infecciones bacterianas y parasitarias del higado. Medicine. 10: 563-569.

Cortés-Jofré, M; Rueda, JR; Corsini-Muñoz, G; Fonseca-Cortés, C; Caraballoso, M; BonfillCosp, $X$ (2012). Drugs for preventing lung cancer in healthy people. Cochrane Database Syst. Rev. 10: CD002141.

Cotran, RS; Kumar, V; Fausto, N; Nelso F; Robbins, SL; Abbas, AK (2005). Robbins and Cotran pathologic basis of disease. $7^{\text {th }}$ ed., Elsevier Saunders, St. Louis, MO, p. 878
Eesha, BR; Mohanbabu Amberkar, V; Meena Kumari, K; Sarath, B; Vijay, M; Lalit, M; Rajput, R (2011). Hepatoprotective activity of Terminalia paniculata against paracetamol induced hepatocellular damage in Wistar albino rats. Asian Pac. J. Trop. Med. 4: 466-469.

Gaafa, KM; Badawy, MM; Hamza, AM (2011). The Protective Effects of Ascorbic Acid, Cimetidine, and Nifidipine on DiethyldithiocarbamateInduced Hepatic Toxicity in Albino Rats. Drug Chem. Toxicol. 34(4):405-419.

Grzybowski, A; Pietrzak, K (2013). Albert SzentGyorgyi (1893-1986): the scientist who discovered vitamin C. Clin. Dermatol. 31(3): 32731

Hirschfield, GM; Gershwin, ME (2013). The immunobiology and pathophysiology of primary biliary cirrhosis. Annu. Rev. Pathol. 8: 303-30.

Jaeschke, H; Knight, TR; Bajt, ML (2003). The role of oxidant stress and reactive nitrogen species in acetaminophen hepatotoxicity. Toxicol. Lett. 144: 279-288.

Kupeli, E; Orhan, DD; Yesilada, E (2006). Effect of Cistus laurifolius L. leaf extracts and flavonoids on a covalent binding in hamsters. Evidence that in vitro covalent binding differs from that in vivo. Drug Metab. Dispos. 12(3): 271-9

Larson, AM (2007). Acetaminophen hepatotoxicity. Clin. Liver Dis. 11: 525-548.

Luo, J; Shen, L; Zheng, D (2014). Association between vitamin $C$ intake and lung cancer: a doseresponse meta-analysis. Sci. Rep. 4: 6161.

McClatchey, KD (2002). Clinical laboratory medicine. Lippincott Williams \& Wilkins, p. 288

Misra, HP; Fridovich, I (1972). The role of superoxide in the autoxidation of Epinephrine and simple assay for superoxide dismutase. J. Biol. Chem. 27: 3170.

Mitra, A; Kulkarni, AP; Ravikumar, VC; Bourcier, DR (1991). Effect of ascorbic acid esters on hepatic glutathione levels in mice treated with a hepatotoxic dose of acetaminophen. J. Biochem. Toxicol. 6(2): 93-100.

Mor, F; Ozmen, O (2010). Effect of vitamin C in reducing the toxicity of endosulfan in liver in rabbits. Exp. Toxicol. Pathol. 62: 75-80. 
Presser, A (2000). Pharmacist's Guide to Medicinal Herbs. Smart Publications, Petaluma, CA, p. 259260 .

Ramachandra, SS; Quereshi, AA; Viswanath Swamy, AH; Patil, T; Prakash, T; Prabhu, K; Veeran Gouda, A (2007). Hepatoprotective activity of Calotropis procera flowers against paracetamolinduced hepatic injury in rats. Fitoterapia. 78: 451-454.

Rang, HP; Dale, MM; Ritter, JM; Flower, RJ (2007). Rang and Dale's Pharmacology, $6^{\text {th }}$ ed. Churchill LivingStone Elsevier, USA, p. 751-764.

Reitman, S; Frankel, S (1957). A colorimetric method for the determination of serum glutamic oxalacetic and glutamic pyruvic transaminases. Am. J. Clin. Pathol. 28: 56-63.
Roy, AV (1970). Rapid method for determining alkaline phosphatase activity in serum with thymolphthalein monophosphate. Clin. Chem. 21: 5.

Sabiu, S; Wudil, AM; Sunmonu, TO (2014). Combined administration of Telfaira occidentalis and Vernonia amygdalina leaf powders ameliorates garlic-induced hepatotoxicity in Wistar rats. Pharmacologia 5: 191-198.

Sinha, AK (1972). Colorimetric assay of catalase. Anal. Biochem. 47: 389-394.

Stratton, J; Godwin, M (2011). The effect of supplemental vitamins and minerals on the development of prostate cancer: a systematic review and meta-analysis. Fam. Pract. 28(3): 243-52. 